\title{
Characterization of lime plaster of a Portuguese medieval monument in the Indian Ocean coast
}

\author{
M. P. Sujith ${ }^{1, *}$, L. Rajeswari ${ }^{2}$ and G. Santhana Krishnan ${ }^{3}$ \\ ${ }^{1}$ Archaeological Survey of India, Ajanta Caves and Conservation Research Laboratory, Aurangabad 431 002, India \\ ${ }^{2}$ Archaeological Survey of India, Southern Division, CGO Complex, Kavadiguda, Hyderabad 500 080, India \\ ${ }^{3}$ Material Science Division, CSIR-National Aerospace Laboratories, Bengaluru 560017 , India
}

The present study aimed to unravel important features regarding the ancient lime plaster of a Portuguese monument in the Indian Ocean coast for the formulation of compatible repairing materials and to determine its condition to plan conservation works. The study illustrates the hydraulic properties of lime used for the construction, the extent of salt intrusion into the plasters, area of intrusion and its source. Wet chemistry results reveal that the dampness and capillary actions led to salt diffusion into the walls and its percolation to different heights of the monument. Due to the intrusion of water into the matrix of the plaster, its inner core becomes less cohesive, resulting in brittleness of lime combination and peeling-off of the upper fabric. Thermal techniques, $X$-ray diffraction and $X$-ray fluorescence results identified the mineralogical composition of the construction materials, viz. lime plaster and mortar. Further, they confirmed the uniqueness of lime combination used to build the monument with lime-silica ratio in the range $1: 1$ to $4: 1$ and its transformations over a period of time in saline atmosphere. This study provides an overview regarding the ancient lime plaster used in the monument and may help to devise new compatible materials for subsequent conservation works.

Keywords: Ancient monument, chemical and mineralogical analysis, coastal sites, lime plaster, salt intrusion.

WEATHERING due to the action of salt on archaeological buildings and objects is widely recognized as one of the main causes for deterioration of heritage structures and $\operatorname{artifacts}^{1}$. The impact of salt aerosol ${ }^{2}$ on historical monuments has been extensively discussed ${ }^{2}$. It affects the coastal structures and monuments as they are exposed to the climatic variations and characteristics unless protected by special methods. Diffusion, crystallization and salt exudation are important processes in the formation of salt layer on the surface of the monuments ${ }^{3-12}$. Salts can damage stone and other building materials through a range of mechanisms like differential thermal expansion,

*For correspondence. (e-mail: sujith.payyanur@gmail.com) osmotic swelling of clays, crystallization pressure, hydration pressure and enhanced wet/dry cycles caused by deliquescent salts ${ }^{13-15}$.

The natural and artificial porous media are contaminated by salts in different ways. Salts can originate from incompatible building materials and inappropriate treatments, air pollution, de-icing treatments and soil. Moisture and groundwater rising from the foundation are other sources to consider. Some materials may inherently contain salts. Salt deposition in buildings and monuments located at coastal sites is mainly due to marine aerosol ${ }^{16,17}$.

Due to urbanization, the deep-rooted trees and plants are being removed and the water table is moving up. This causes salt movement to the surface that subsequently gets evaporated to the atmosphere. Hence, the salt depositions on the coastal structures monuments are rampant with the urbanization and is true in the case of Cochin city, Kerala, India. The environmental features and proximity to water bodies accelerate the decay of lime-based medicinal structures. Figure 1 shows the location map and general view of St Francis Church, Kochi, southern India. The church, carries great value for its Neo-Roman structure resembling characteristics from Manueline Gothic and Portuguese styles. It is the oldest church in India ${ }^{18}$, built in circa $\mathrm{AD} 1516$ by the Portuguese and later conserved by the Dutch in circa AD 1663.

Horizontal profiles from north to south and west to east plotted using geographical information system show the elevation of the monument from the mean sea level (Figure 2). The profiles show that the monument is approximately $10 \mathrm{~m}$ amsl. This underlines the possibility of capillary intrusion salts through the sand bed below the base of Church.

Figure $3 a-d$ shows the interior views of the church. It has a prayer hall, altar chamber and a balcony for special guests. The building material used was lime mortar, plaster and wood. The monument has survived for five centuries and remains as an example of European structures of medieval India. The body of the Portuguese explorer Vasco da Gama was buried in this church for 14 years before it was taken to Lisbon, Portugal. In his last voyage, Vasco da Gama arrived in Kochi in circa AD 1524 

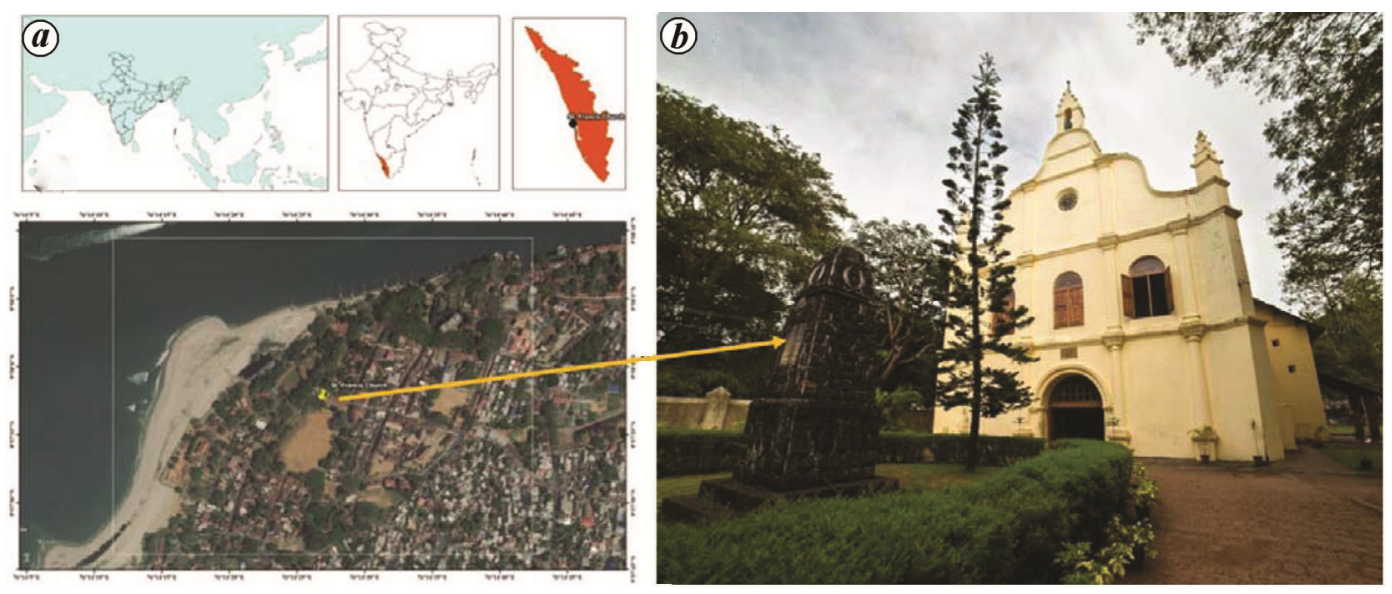

Figure 1. $\boldsymbol{a}$, Location map of St Francis Church, Kochi, Kerala, India. b, General view of the Church.

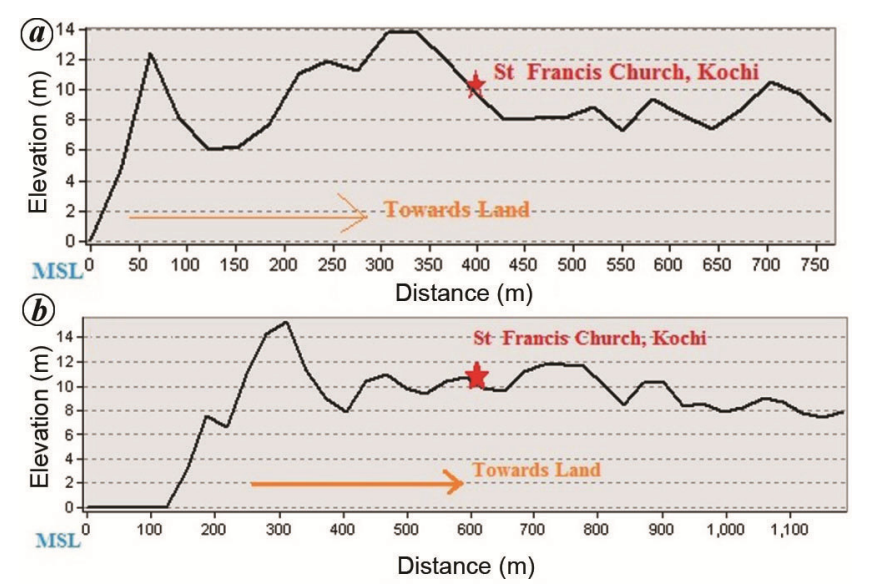

Figure 2. Horizontal profile from (a) north to south. (b) west to east (MSL, mean sea level).

and died at the same place in December AD 1554. He was the first European voyager who introduced a sea route from Europe to India for trade. His first voyage to Calicut in $\mathrm{AD} 1498$ and meeting with Zamorine of Calicut are considered as important milestones in Indian as well as European history. Since 1923, St Francis Church is a protected monument under the Archaeological Survey of India (ASI), one of the premier agencies for protection and conservation of monuments and antiquities in the country.

Ancient buildings endure damage due to salt action and dampness, which result in disintegration of building masonry such as upper plaster fabric layer, lime mortar and stones, etc. ${ }^{19-21}$. Studies on medieval mortars reveal that European, especially Roman mortars are known for their durability ${ }^{2-27}$. These studies generally focused on mineralogical, chemical and mechanical properties.

St Francis Church has witnessed the disintegration of building materials due to the loss of binding strength of lime plaster over the past several decades. The aim of the present study is to obtain data that are useful for the resto- ration and conservation of ancient monuments protected by ASI. The present study aimed to evaluate the surface area and extent of penetration of saline content into the matrix of ancient plaster with laterite support which is upsetting the ancient building material of the structure.

Based on the study results, conservation efforts were taken to safeguard the fragile portions and consolidations carried out to preserve the ancient lime plaster as much as possible. There was loosening of lime plaster from the fittings in the altar chamber. The reasons for the deterioration the lime plaster were analysed. The lime plaster samples were subjected to evaluation of elemental composition and contents in lime using conductivity, salinity, total dissolved solids (TDS), $\mathrm{pH}$ analysis, X-ray fluorescence spectroscopy (XRF) and X-ray diffraction (XRD) studies. The study was further widened through the wet chemical analysis of lime samples for conductivity at various levels for all the four interior walls in vertical lengths. The results further correlated with those of XRF, XRD, SEM-EDS and TG-DTA analyses. The results of this study can help in conservation activities of similar monuments in India as well as in Southeast Asia and Oceania.

\section{Materials and methods}

\section{Sample collection and preparation}

The location map and contour of St Francis Church, shows that the historical monument is situated $10 \mathrm{~m}$ amsl and is approximately $250 \mathrm{~m}$ away from the seashore. This may makes the monument prone to capillary action as well as damage caused by wind blowing from the Arabian $\mathrm{Sea}^{28}$. Selective sample collections were done in the study. The locations of the samples collected from the church are shown in Figure 4 to assess deformity at different locations. The details of the samples are given below.

Figure 5 shows a representative lime plaster image of St Francis Church. 

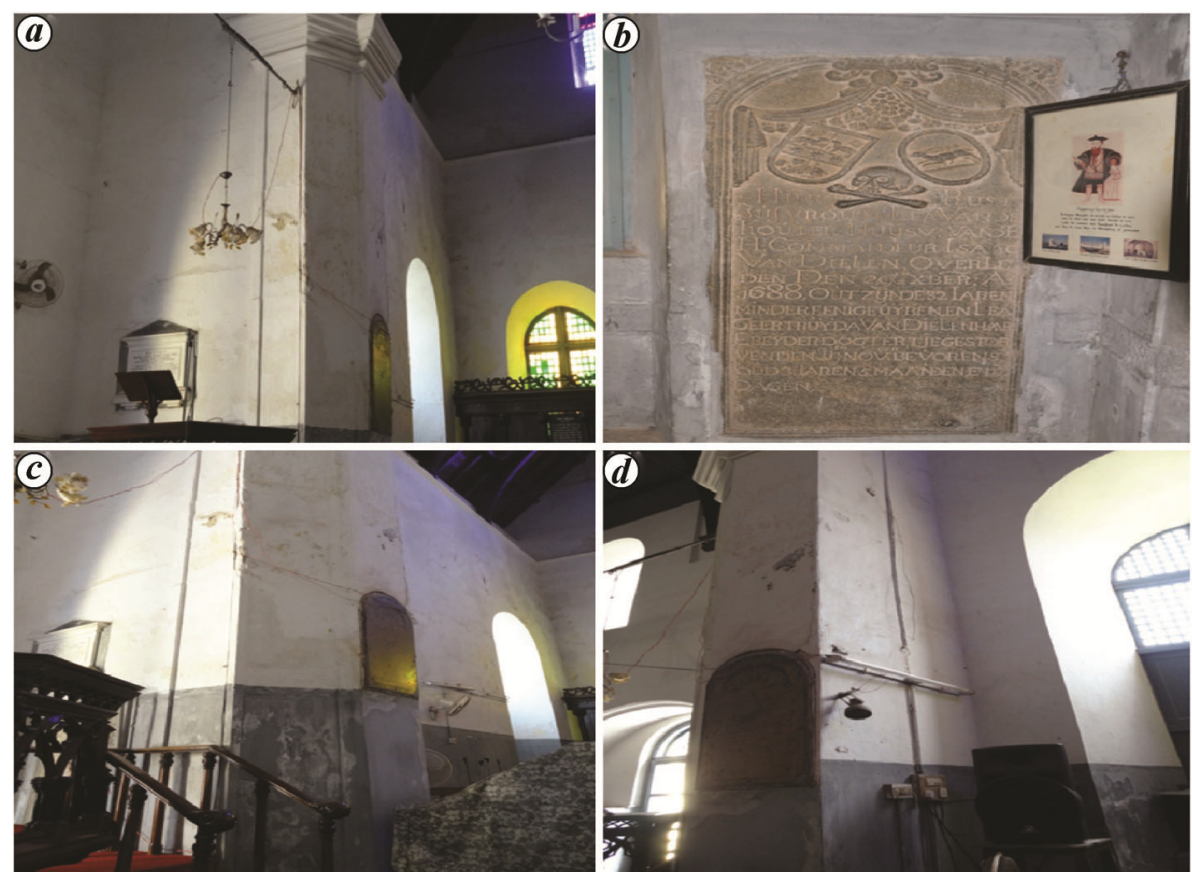

Figure $3 \boldsymbol{a}-\boldsymbol{d}$. Interior views of St Francis Church.

PLAN OF ST FRANCIS CHURCH FORT COCHIN, COCHIN TALUK, ERNAKULAM DISTRICT, KERALA AREA-67 CENTS

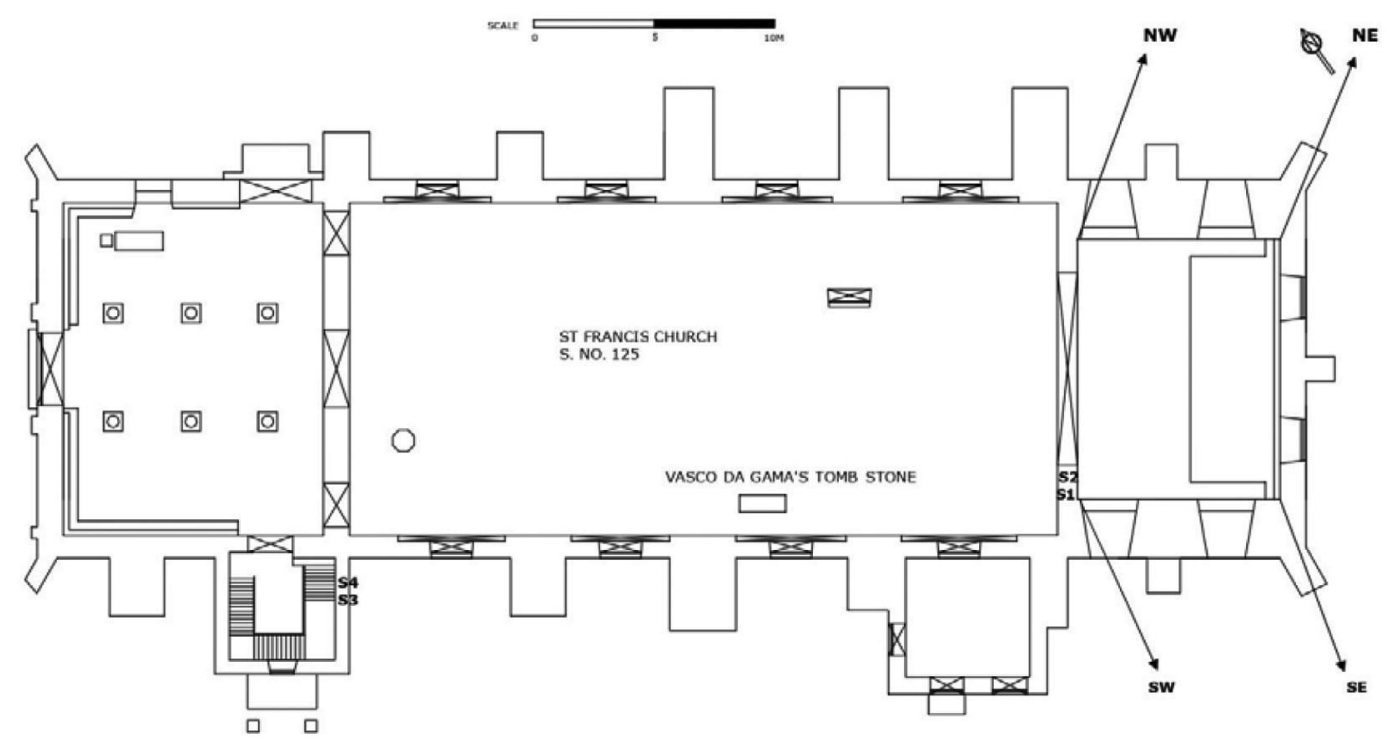

Figure 4. Plan of St Francis Church, showing the location of lime plaster samples collected for the study.

I - The lime plaster samples were extracted from walls in the altar chamber (loose powdery lime sample) at a distance of $1.4 \mathrm{~m}$ on right-hand side (S1) and at a height of $1.9 \mathrm{~m}$ from the ground (S2) as well as exterior walls to the right of the main entrance. In addition, an exposed stone sample from the exterior wall was extracted from masonry (Outer wall $1.4 \mathrm{~m}$ from the southern end and $0.7 \mathrm{~m}$ from the bottom), (S3) was collected from the southern wall at a height of 1.0 and $0.2 \mathrm{~m}$ from southern end respectively and both were at $1.3 \mathrm{~m}$ from the floor. $\mathrm{S} 4$ was extracted from the outer western wall $1.4 \mathrm{~m}$ from the southern end and $0.7 \mathrm{~m}$ from the bottom. Samples were extracted in random from the altar inside and outside, where disintegration of mortar was prominent.

II - Samples were collected from below $5 \mathrm{~m}$ in random from the altar chamber inside and outside where disintegration of mortar was prominent. These were numbered as S5-S7.

CURRENT SCIENCE, VOL. 120, NO. 3, 10 FEBRUARY 2021 
III - Samples were collected from a height of 2.5, 4.5, 6.5 and $8.5 \mathrm{~m}$ at two different locations of the northern and southern walls of the altar chamber in eastern and western directions (total 16 samples) for a proper comparison based on visual observations; they were numbered according to the direction with a suffix of their height. These are numbered accordingly with abbreviations for their locations with suffix of their heights from the ground. The samples $(5 \mathrm{~g}$ was sparingly dissolved in $100 \mathrm{ml}$ demineralized water) NW2.5, SW2.5, NE2.5, SE2.5 were used for analysis of $\mathrm{pH}$, conductivity, TDS and salinity. XRD analyses of the samples were performed to determine the lime-sand (binder filler) ratio and finally a comparison was made of salt in the selected samples based on SEM and TG-DTA.

\section{Methods of analysis}

Bulk densities and porosities of lime plaster were determined by RILEM standard test method ${ }^{29}$. Measurement of density and porosity was carried out on two samples of each plaster. The samples were dried in an oven at $40^{\circ} \mathrm{C}$ for $24 \mathrm{~h}$. Then the weight of the plaster was measured by precision balance for obtaining dry weight $\left(M_{\text {dry }}\right)$. Subsequently, they were saturated with water in a vacuum oven. The saturated weight $\left(M_{\text {sat }}\right)$ and Archimedes weight $\left(M_{\text {arch }}\right)$ that determined with hydrostatic weighing in distilled water were also measured with precision balance. Then, bulk density $(D)$ and porosity $(P)$ of the plaster were obtained using the formulas given below.

$$
\begin{aligned}
& D\left(\mathrm{~g} / \mathrm{cm}^{3}\right)=M_{\mathrm{dry}} /\left(M_{\mathrm{sat}}-M_{\mathrm{arch}}\right), \\
& P(\%)=\left[\left(M_{\mathrm{sat}}-M_{\mathrm{dry}}\right) /\left(M_{\mathrm{sat}}-M_{\mathrm{arch}}\right)\right] \times 100 .
\end{aligned}
$$

Systronics water analyser (model 371-GE \& RE)combined electrodes with precision levels $\mathrm{pH}$ meter accuracy $\pm 0.01, \mathrm{pH} \pm 1$ digit; conductivity/TDS $\pm 1 \%$ of FS \pm 1 digit; salinity $\pm 1 \%$ of FS \pm 1 were used for $\mathrm{pH}$, conductivity, TDS and salinity studies respectively (Table 1).

Next, $25 \mathrm{ml}$ of distilled water was added to $1 \mathrm{~g}$ sample of lime mortar in a $50 \mathrm{ml}$ beaker in each case. The sample was stirred with a glass rod and after $2 \mathrm{~h}$ a few drops of $5 \%$ dilute nitric acid was added to each solution. A blank was also prepared without sample. Then $10 \mathrm{ml}$ clear solution from the upper layer was decanted and few drops of $2 \%$ silver nitrate solution were added to the test solutions and blank. The difference in white precipitate from the test sample to the blank provided information regarding salt content in the test solutions. Table 2 gives the results of silver nitrate test assessing the extent of salt in each sample.

XRD analysis was done for qualitative identification of different salts and their mineral components of lime plaster (sample utilized $500 \mathrm{mg}$ ) using the 'X'pert PRO diffractometer system with $\mathrm{CuK} \alpha_{1}$ radiation ( $\lambda=$ $1.54060 \AA), \mathrm{CuK} \alpha_{2}$ radiation $(\lambda=1.5443 \AA)$, continuous scans explored area 0 to 70 with goniometer speed 0.001 $2 \theta /$ s. Bruker model S4 Pioneer sequential wavelengthdispersive X-ray spectrometer was used (sample utilized $2 \mathrm{~g}$ ) for XRF studies. Hitachi Model S-3400N PC-based variable pressure scanning electron microscope (SEM) was used for surface morphology. NETZSCH STA 2500 simultaneous Thermal analysers was used for TG-DTA and the study was carried out in nitrogen atmosphere. About $10 \mathrm{mg}$ of sample was utilized for thermal analysis using silica crucible. Thermal mass loss curves with heat flow were observed in the range $30^{\circ}-900^{\circ} \mathrm{C}$ at a heating rate of $10^{\circ} \mathrm{C} / \mathrm{min}$.

Table 1. Values of $\mathrm{pH}$, conductivity, total dissolved solids and salinity of samples from the inner and outer portions of the altar

\begin{tabular}{lcccc}
\hline & $\begin{array}{c}\mathrm{pH} \\
\left(@ 25^{\circ} \mathrm{C}\right)\end{array}$ & $\begin{array}{c}\text { Conductivity } \\
\left(\mu \mathrm{S} / \mathrm{cm} @ 25^{\circ} \mathrm{C}\right)\end{array}$ & $\begin{array}{c}\text { TDS } \\
(\mathrm{ppm})\end{array}$ & $\begin{array}{c}\text { Salinity } \\
\left(\mathrm{ppm} @ 27^{\circ} \mathrm{C}\right)\end{array}$ \\
Sample & 4.94 & 4540 & 2900 & 1890 \\
S1 & 6.40 & 1150 & 930 & 890 \\
S2 & 6.68 & 1240 & 950 & 1170 \\
S3 & 6.11 & 742 & 480 & 500 \\
S4 & & &
\end{tabular}
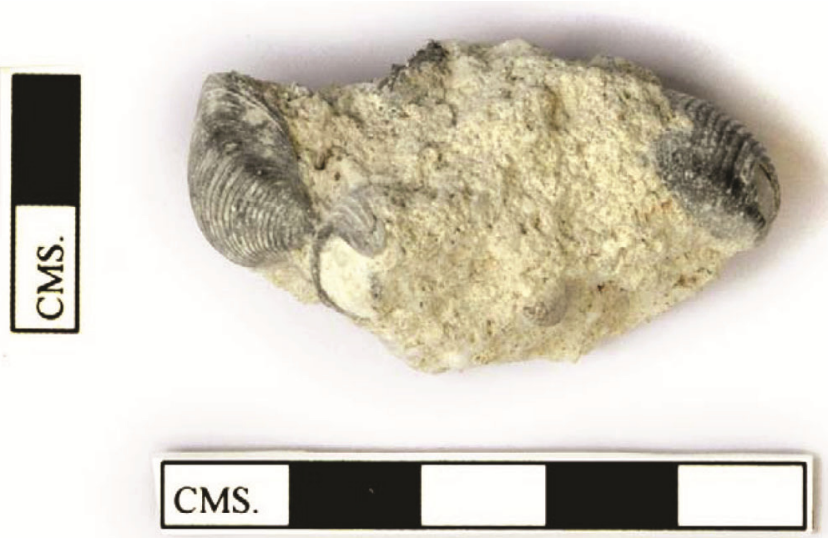

Figure 5. Lime plaster from St Francis Church

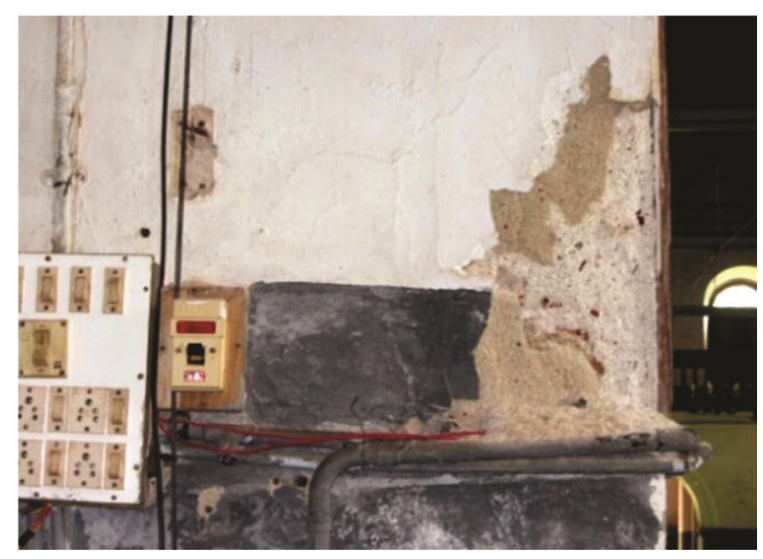

Figure 6. Damaged inner wall fabric of St Francis Church. 
Table 2. Qualitative analysis of mortar samples from different heights inside the altar using silver nitrate

\begin{tabular}{llll}
\hline Sample ID & Sample location & \multicolumn{1}{c}{ Silver nitrate test } & \multicolumn{1}{c}{ Inference } \\
\hline NW-2.5 & Altar & White precipitate & Presence of salt \\
NW-4.5 & Altar & White precipitate & Presence of salt \\
NW-6.5 & Altar & Less white precipitate & Less presence of salt \\
NW-8.5 & Altar & Feeble white precipitate & Feeble presence of salt \\
SW-2.5 & Altar & White precipitate & Presence of salt \\
SW-4.5 & Altar & White precipitate & Presence of salt \\
SW-6.5 & Altar & Less white precipitate & Less presence of salt \\
SW-8.5 & Altar & Feeble white precipitate & Feeble presence of salt \\
NE-2.5 & Altar & White precipitate & Presence of salt \\
NE-4.5 & Altar & Less white precipitate & Less presence of salt \\
NE-6.5 & Altar & Feeble white precipitate & Feeble presence of salt \\
NE-8.5 & Altar & Feeble white precipitate & Feeble presence of salt \\
SE-2.5 & Altar & White precipitate & Presence of salt \\
SE-4.5 & Altar & Less white precipitate & Less presence of salt \\
SE-6.5 & Altar & Feeble white precipitate & Feeble presence of salt \\
SE-8.5 & Altar & Feeble white precipitate & Feeble presence of salt \\
\hline
\end{tabular}

NW, Northwest; NE, Northeast; SW, Southwest and SE, Southeast. Presence of salt may be possibly chlorides.

\section{Results and discussion}

\section{$p H$, conductivity, TDS and salinity of analysed samples}

It is evident from Figure 6 that the damage caused is severe. Table 1 presents wet chemistry data of samples S1-S4. Samples S1-S3 where excessive damage was noticed, had $\mathrm{pH}$ in the acidic range; conductivity and TDS were also excessive. Therefore, conservation measures are inevitable in these areas, whereas the other locations showed $\mathrm{pH}$ almost close to neutral. Conductivity, salinity and TDS evaluation showed that the salt content in S1 was comparatively more, whereas S2 and S3 also contained in substantial levels of salt. It can be inferred from the results that salt crystallization is occurring in these regions. In $\mathrm{S} 4$ (stone sample), salt content was very less; this shows that the deposition of salt in the stone layer is relatively less whereas the lime plaster sample from the same location contains some extent of salt.

As the building materials used in this edifice are laterite stone and lime mortar, due to their porous nature, there is possibility of dampness which leads to salinity problems. Moreover, due to diurnal temperature variation and wind from the sea in this coastal region, the damage caused is obvious ${ }^{30,31}$ High temperature, precipitation and fluctuation in relative humidity influence climatic conditions that directly affect salt weathering in porous building materials ${ }^{32}$.

Table 2 provides the results of the qualitative analysis of the 16 samples. The results are found to vary and salinity is present more on the lower parts of the walls irrespective of the direction of the wall from samples collected. The results imply that up to a level of $4.5 \mathrm{~m}$, there is concentration of salt in the lime plaster matrix which can be attributed to capillary action from the floor. Though damp-proof coarse (DPC) granite slabs are now provided at the exterior of the church, the capillary action from the inner parts of the base still continues ${ }^{33-35}$. Table 3 shows the results of base-line analysis. NW-2.5, SW-2.5, NE-2.5, SE-2.5 show that there is a concentration of salt to an extent of $1.26 \%$ in the lime samples collected. The $\mathrm{pH}$ of samples are in the range 5.04-6.35, which shows they are almost neutral, whereas conductivity and TDS show the presence of salt. Thus salt accumulation is more in the northwest and southwest regions of the altar chamber.

\section{$X$-ray fluorescence}

The chemical composition of the construction materials used in this monument is considered important from future restoration point of view. Conservation materials of similar composition and properties will greatly enhance the physical strength and aesthetics of the monument. XRF analysis results confirm the presence of oxides of elements like $\mathrm{Ca}, \mathrm{Si}, \mathrm{Al}, \mathrm{Mg}, \mathrm{Na}, \mathrm{K}$ and $\mathrm{Fe}$ in the three random samples taken from inside and outside of altar (Table 4). XRF analysis also shows that the combination ratio of calcium and silica in lime in the lower areas of the altar chamber consistently remains $1: 1$ with considerable presence of alumina in all the samples. Thus it can be inferred that the binder is calcite found with silica aggregates incorporated with minerals of $\mathrm{Al}, \mathrm{Mg}$ and salts of $\mathrm{Na}, \mathrm{K}$. Magnesium oxide was found to be $2.0 \%$ in the inside plaster of the altar chamber. This confirms the presence of magnesium calcite.

The presence of higher amounts of $\mathrm{CaO}, \mathrm{SiO}_{2}$ and $\mathrm{Al}_{2} \mathrm{O}_{3}$ indicate hydraulic reaction products as calcium-silicatehydrate $(\mathrm{Ca}-\mathrm{Si}-\mathrm{H})$ and calcium-aluminium-hydrate 
$(\mathrm{Ca}-\mathrm{Al}-\mathrm{H})$. Presence of these minerals must have improved the strength of the mortar to a great extent.

The total concentration of sodium and potassium oxide together is $5.02 \%$, with individual values of sodium and potassium oxide being $2.16 \%$ and $2.86 \%$ respectively. The presence of sodium and potassium oxide might be due to ample salt in the samples of the plaster and mortar from inside of the altar. Whereas for the sample taken from the outside it was $1.37 \%$ and $2.76 \%$ with combined value of $4.13 \%$. XRF results of lime plaster from inside the altar chamber showed total oxide content of sodium and potassium as $4.81 \%$.

\section{$X$-ray diffraction studies}

Figure 7 shows the XRD spectra of lime plaster samples from different points of deterioration. The results illustrate that calcite $\left(\mathrm{CaCO}_{3}\right)$ combined with magnesium calcite $\left(\mathrm{CaMg}\left(\mathrm{CO}_{3}\right)_{2}\right)$ is the major component in the lime mortar used for building the monument and the binder filler ratio for calcite and quartz is approximately $1: 1$ to $4: 1$. Calcium content is comparatively more at heights beyond $2.5 \mathrm{~m}$. Physical examination of the lime samples at heights beyond $2.5 \mathrm{~m}$ revealed that the lime is obtained from sea shells. Kyanite $\left(\mathrm{Al}_{2} \mathrm{SiO}_{5}\right)$ and garnet $\left(\mathrm{Fe}_{3} \mathrm{Al}_{2} \mathrm{Si}_{3} \mathrm{O}_{12}\right)$ are the other minerals present in the lime mortar. NE2.5, NW2.5 and NW8.5 showed approximately $50 \%$ of calcite; this may be due to leaching of lime from damp mortar in the lower portions. Along with the minerals, salts were also identified in the form of sodium

Table 3. Values of $\mathrm{pH}$, conductivity, TDS and salinity of samples from different walls inside the altar at $2.5 \mathrm{~m}$ height from the floor

\begin{tabular}{lcccc}
\hline & $\begin{array}{c}\mathrm{pH} \\
\left(@ 30^{\circ} \mathrm{C}\right)\end{array}$ & $\begin{array}{c}\text { Conductivity } \\
\left(\mu \mathrm{S} / \mathrm{cm} @ 25^{\circ} \mathrm{C}\right)\end{array}$ & $\begin{array}{c}\mathrm{TDS} \\
\left(\mathrm{ppm} @ 30^{\circ} \mathrm{C}\right)\end{array}$ & $\begin{array}{c}\text { Salinity } \\
\left(\mathrm{ppm} @ 30^{\circ} \mathrm{C}\right)\end{array}$ \\
\hline $\mathrm{NW}-2.5$ & 5.04 & 973 & 470 & 140 \\
$\mathrm{SW}-2.5$ & 5.68 & 1190 & 630 & 190 \\
$\mathrm{NE}-2.5$ & 6.15 & 245 & 159 & 140 \\
$\mathrm{SE}-2.5$ & 6.35 & 285 & 150 & 50 \\
\hline
\end{tabular}

Table 4. Chemical composition of lime plaster samples from the inner and outer portions of the altar identified by XRF

\begin{tabular}{lccc}
\hline Sample ID & $\begin{array}{c}\text { Mortar from } \\
\text { inside S5 }\end{array}$ & $\begin{array}{c}\text { Mortar from } \\
\text { outside S6 }\end{array}$ & $\begin{array}{c}\text { Plaster from } \\
\text { inside S7 }\end{array}$ \\
\hline $\mathrm{SiO}_{2}$ & 38.45 & 46.00 & 40.57 \\
$\mathrm{TiO}_{2}$ & 0.30 & 0.41 & 0.36 \\
$\mathrm{Al}_{2} \mathrm{O}_{3}$ & 7.80 & 10.51 & 7.31 \\
$\mathrm{MnO}_{\mathrm{Fe}} \mathrm{O}_{3}$ & 0.01 & 0.01 & $\mathrm{ND}$ \\
$\mathrm{CaO}$ & 1.19 & 2.14 & 0.45 \\
$\mathrm{MgO}$ & 46.25 & 35.68 & 43.15 \\
$\mathrm{Na}$ & 0.61 & 0.71 & 2.84 \\
$\mathrm{~K}_{2} \mathrm{O}$ & 2.16 & 1.37 & 1.82 \\
$\mathrm{P}_{2} \mathrm{O}_{5}$ & 2.86 & 2.76 & 2.99 \\
Total & 0.16 & 0.16 & 0.16 \\
\hline
\end{tabular}

CURRENT SCIENCE, VOL. 120, NO. 3, 10 FEBRUARY 2021 chloride, potassium chloride as sylvite and halite respectively. According to ASI records, no major conservation has been carried out for the structure in the altar chamber. However, there are possibilities of localized conservation as observed from the XRD pattern of sample NE 2.5. The chemical composition of the wall lime plaster at different heights varies significantly as the sample height changes from 2.5 to $8.5 \mathrm{~m}$ in both NE and NW samples. The presence of calcite, quartz and kyanite in XRD shows the consistency of the results with XRF that the hydraulic reaction products are calcium-silicate-hydrate and calcium-aluminium-hydrate.

\section{$S E M-E D S$}

Figure 8 shows SEM photomicrograph with magnification of $3000 \times$ and $6000 \times$ respectively. Tables 5 and 6 show SEM-EDS analysis of the samples. The results reveal that the sample collected from the lower part of the wall has sodium up to $1.77 \%$; this can be attributed to the presence of sodium chloride. In sample NW8.5 only potassium is present and sodium is minimum. This stresses the fact that salt presence in the lower parts is more significant. From the SEM photomicrographs, calcite, kyanite and garnet minerals were found to be the main constituents of lime plaster. In addition, quartz is also noticed. The aggregate fragments of the plaster were examined by EDS analysis. Tables 5 and 6 show the results for samples NW-2.5 m and NW-8.5 m respectively. EDS analysis elucidates the possibility of garnet, kyanite, quartz and calcite as common minerals due to the presence of $\mathrm{Si}$ and $\mathrm{Ca}$. However, the plaster representing the samples is shown to contain sodium and potassium that might be due to the presence of salts. The results show good correlation with the chemical composition results, XRD and TGA-DTA analyses.

\section{Thermogravimetry-coupled differential thermal analyser}

TG-DTA was employed to understand the thermal degradation behaviour and stability of lime plaster samples collected from different locations of the Church. Figure 9 shows the thermal mass loss curves of lime plaster samples collected from different locations in the monument. The thermal mass loss curve along with heat flow of lime plaster sample at height of $8.5 \mathrm{~m}$ in the altar chamber is significantly different from that at $2.5 \mathrm{~m}$. It is observed that there is a sudden thermal degradation of mass amounting to an overall mass loss of $40 \% \mathrm{wt}$ in the previous one compared to $12 \%$ wt in the latter, which is gradual and steady. It can be attributed to release of hygroscopic or occluded water and release of water of hydration between $100^{\circ} \mathrm{C}$ and $300^{\circ} \mathrm{C}$. The release of carbon dioxide and weight loss attached to it is visible from the 

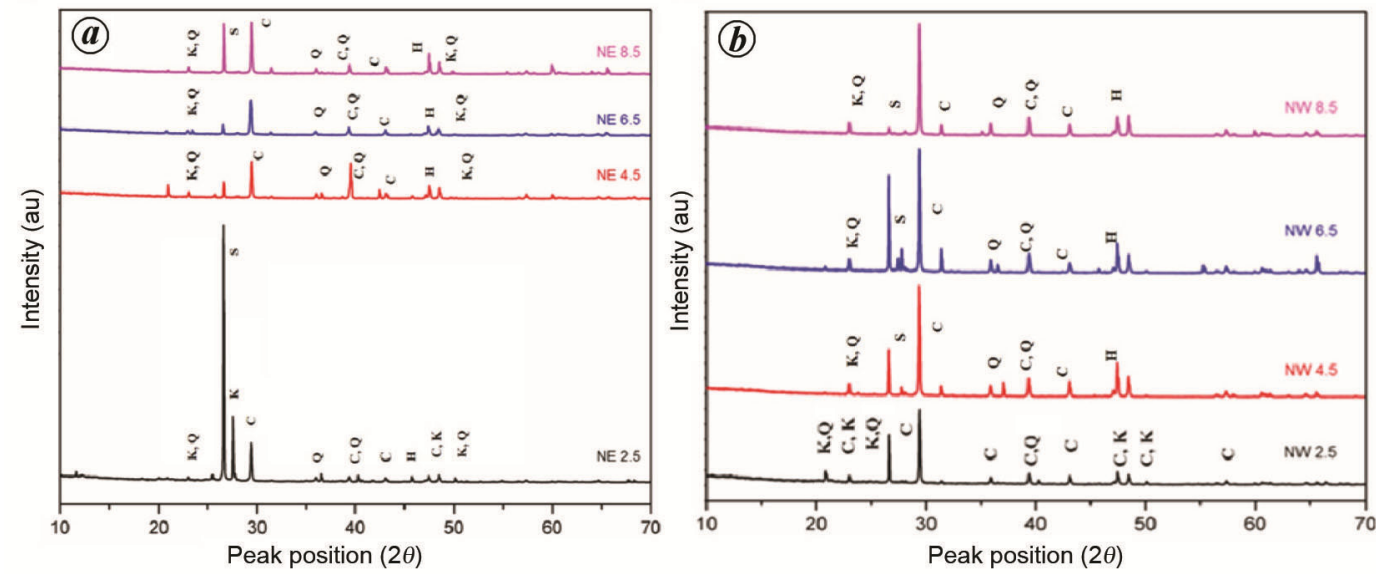

Figure 7. X-ray diffraction pattern of lime plaster samples from different points of deterioration from $(\boldsymbol{a})$ northeast and (b) northwest portions of the altar (K, Kyanite; C, Calcite; Q, Quartz; S, Sylvite and H, Halite).
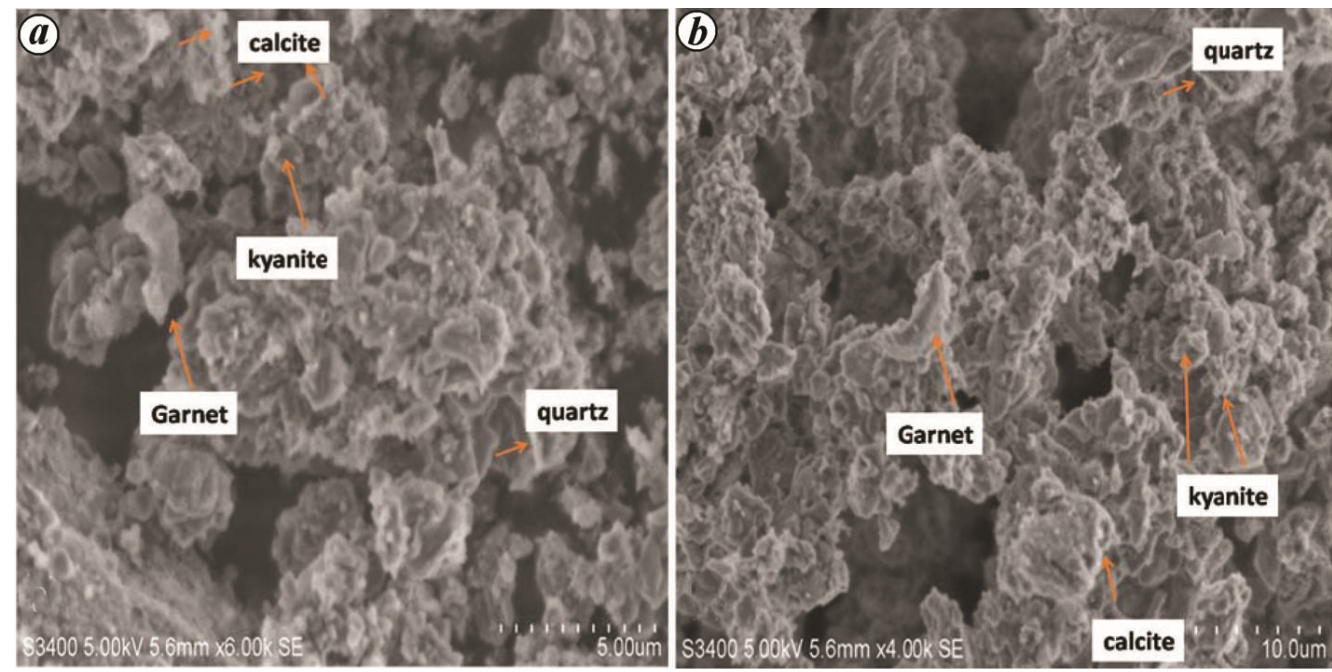

Figure 8. SEM image of lime plaster samples from $(\boldsymbol{a})$ NE and $(\boldsymbol{b})$ NW portions of the altar.
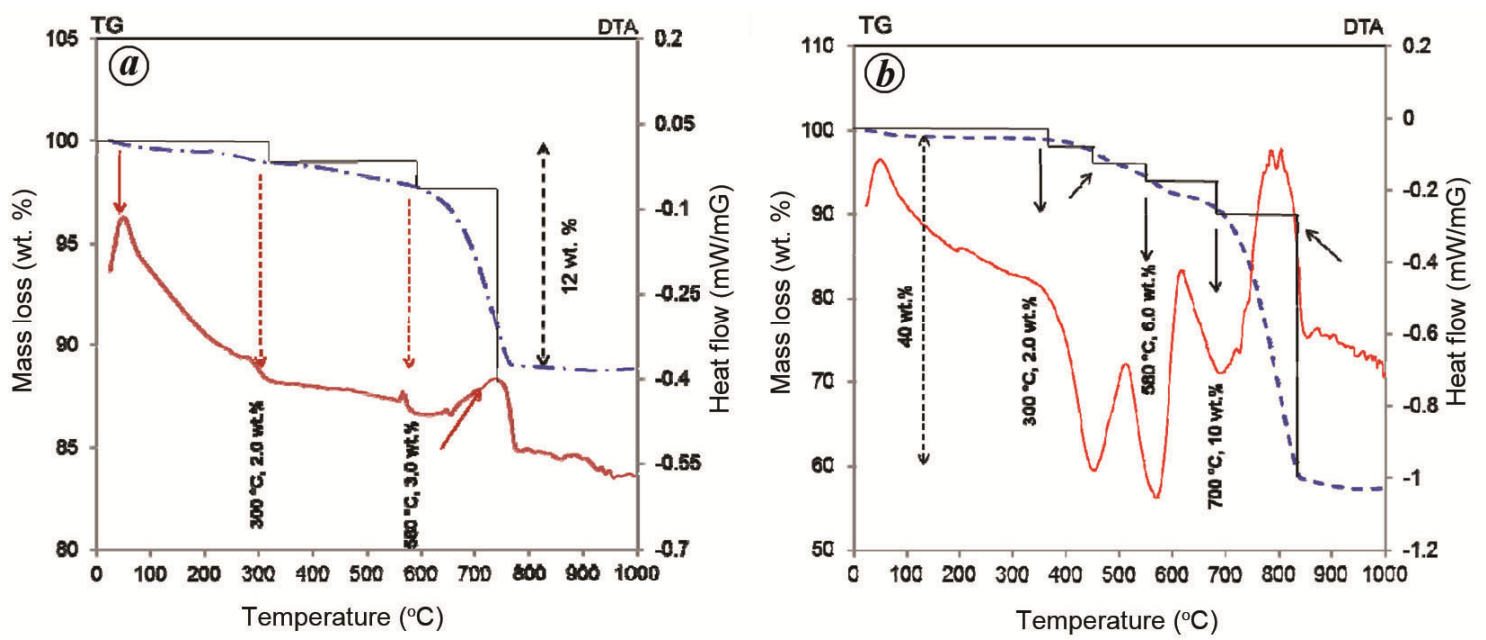

Figure 9. $\boldsymbol{a}$, TG-DTA curves of lime plaster samples collected at the height of $2.5 \mathrm{~m}$. $\boldsymbol{b}$, TG-DTA curve of lime plaster samples collected from the bottom NW portion of the altar. 
Table 5. SEM-EDS analysis of sample NW-2.5 m

\begin{tabular}{lccc}
\hline Element line & Weight $(\%)$ & Weight \% error & Atom $(\%)$ \\
\hline C K & 13.82 & \pm 0.76 & 20.92 \\
O K & 56.07 & \pm 1.16 & 63.71 \\
$\mathrm{Na} \mathrm{K}$ & 1.77 & \pm 0.24 & 1.40 \\
$\mathrm{Mg} \mathrm{K}$ & 0.26 & \pm 0.12 & 0.20 \\
$\mathrm{Al} \mathrm{K}$ & 1.46 & \pm 0.13 & 0.99 \\
$\mathrm{Si} \mathrm{K}$ & 3.57 & \pm 0.23 & 2.31 \\
Cl K & 0.36 & \pm 0.10 & 0.18 \\
K K & 0.46 & \pm 0.10 & 0.21 \\
Ca K & 22.22 & \pm 0.62 & 10.08 \\
Total & 100.00 & - & 100.00 \\
\hline
\end{tabular}

Table 6. SEM-EDS analysis of sample NW-8.5 m

\begin{tabular}{lccc}
\hline Element line & Weight $(\%)$ & Weight \% error & Atom (\%) \\
\hline C K & 12.69 & \pm 0.60 & 19.77 \\
O K & 55.92 & \pm 1.18 & 65.40 \\
Mg K & 0.11 & \pm 0.11 & 0.08 \\
Si K & 0.67 & \pm 0.09 & 0.45 \\
Cl K & 0.15 & \pm 0.09 & 0.08 \\
K K & 0.04 & \pm 0.10 & 0.02 \\
Ca K & 30.41 & \pm 0.66 & 14.20 \\
Total & 100.00 & - & 100.00 \\
\hline
\end{tabular}

sharp endothermic peaks around $630^{\circ} \mathrm{C}$ and $770^{\circ} \mathrm{C}$, accounting for the major part of thermal decomposition.

The normal decomposition of calcium carbonate occurs from $600^{\circ} \mathrm{C}$ to $800^{\circ} \mathrm{C}$ temperature range. The ratio of $\mathrm{CO}_{2} / \mathrm{H}_{2} \mathrm{O}$ is less than 10 , which implies that the lime sample is hydraulic in nature ${ }^{36-38}$. On comparison of the two curves, the lime plaster sample at $2.5 \mathrm{~m}$ was found to be more thermally stable than the sample at $8.5 \mathrm{~m}$, implying that the latter is an ancient lime plaster. Further, it can be inferred that conservation works on this monument were probably confined to a height of $2.5 \mathrm{~m}$, where most of the human activities take place. However, at the higher levels, i.e. around $8.5 \mathrm{~m}$, the lime plaster remains ancient and devoid of any conservation activities. Moreover, pure lime found in the plaster at $2.5 \mathrm{~m}$ and lime with traces of unburnt shell found at higher locations also complement the results of thermal analysis. Physical observation, results, XRF, XRD and TGA-DTA analyses of the samples were stable and agrees with the fact that there is formation of structures as $\mathrm{Ca}-\mathrm{Si}-\mathrm{H}$ and $\mathrm{Ca}-\mathrm{Al}-\mathrm{H}$. This is the main reason for durability of the mortar for 500 years.

\section{Conclusion}

(i) The lateritic masonry of St Francis Church in Kochi is plastered with hydraulic lime mortar.

(ii) The major minerals of the lime fabric are calcite, silica, magnesium calcite, kyanite and garnet along with salts $(\mathrm{NaCl}$ and $\mathrm{KCl})$. The durability of lime is due to its $\mathrm{Ca}-\mathrm{Si}-\mathrm{H}$ and $\mathrm{Ca}-\mathrm{Al}-\mathrm{H}$ structural features. These features have been inferred from XRF, XRD, SEM and TG-DTA studies.

(iii) Lime mortar is brittle due to intrusion of salts. The level of salt intrusion in the lime matrix is less than $2 \%$; it is mainly salts of sodium and potassium.

(iv) Salt ingress is contributed by capillary action in the basement and salt-laden wind blowing from the sea coast. The damp proof coarse insertions of granite layers (through the outer walls) have contributed to minimizing the percolation of salt. Capillary action through the inside parts of the foundation is found to be active.

(v) Localized conservation measures are identified at different locations up to $2.5 \mathrm{~m}$ from the floor, while no conservation has been identified above this level.

The challenge in building such ancient monuments at the seashore and their enduring coexistence with nature for over 500 years renders them unique. Utilization of European technology, iconography and legends connected with Vasco da Gama makes this structure exceptional. The present study will be of relevance to compare with similar ancient monuments.

1. Schaffer, R. J. and Building Research Establishment (Great Britain) and Great Britain. Department of Scientific and Industrial Research; The weathering of natural building stones (Facsimile reprint of 1st edn, London, Department of Scientific and Industrial Research). Building Research Establishment, Watford, 1972.

2. Pósfai, M. et al., Compositional variations of sea-salt modeaerosol particles from the North Atlantic. J. Geophys. Res., 1995, 100, 23063-23074.

3. Taber, S., The growth of crystals under external pressure. Am. J. Sci., 1916, 41, 532-556.

4. Jutson, J. T., The influence of salts in rock weathering in sub-arid Western Australia. R. Soc. Victoria, Proc., 1918, 30, 165-172.

5. Nash, D. J., Arid geomorphology. Prog. Phys. Geogr. Earth Environ., 2000, 24, 425-443; doi:10.1177/030913330002400308.

6. Flatt, R. J., Salt damage in porous materials: how high super saturations are generated. J. Cryst. Growth, 2002, 242(3-4), 435454.

7. Charola, A. E. et al., Salts in ceramic bodies IV: considerations on desalination. Int. J. Restor. Build. Monuments, 2001, 7, 161-168.

8. Blaeuer Boehm, C. et al., Salt crystal intergrowth in efflorescence on historic buildings. Chimia, 2001, 55(11), 996-1001.

9. Scherer, G. W., Crystallization in pores. Cem. Concr. Res., 1999, 29, 1347-1358.

10. Scherer, G. W., Stress from crystallization of salt in pores. In 9th International Congress on Deterioration and Conservation of Stone, Venice, 19-24 June 2000, pp. 187-194.

11. Scherer, G. W. et al., Materials science research for the conservation of sculpture and monuments. Mater. Res. Soc. Bull., 2001, 26, $44-50$.

12. Doehne, E., Salt Weathering: A Selective Review, Geological Society, London, Special Publications, 2002, vol. 205, pp. 51-64; 10.1144/GSL.SP.2002.205.01.05.

13. Smith, B. J., Weathering processes and forms. In Geomorphology Desert Environments (eds Parsons, A. J. and Abrahams, A. D.), Springer Dordrecht, The Netherlands, 2009, pp. 69-100; doi:10.1007/978-1-4020-5719-9_4.

14. Lubelli, B. et al., Towards a more effective and reliable salt crystallization test for porous building materials: state-of-the-art. Mater. Struct., 2018, 51, 55; doi:10.1617/s11527-018-1180-5. 
15. Vinodh Kumar, S. and Singh, M., Salt weathering of 7 th century CE granite monument of Shore temple, Mahabalipuram Scientific Investigation and Conservation Strategy. Heritage, January 2019; doi:10.3390/heritage2010017.

16. Zezza, F. and Macri, F., Marine aerosol and stone decay. Sci. Total Environ., 1995, 167, 123-143.

17. Moropoulou, A., Theoulakis, P. and Chrysophakis, T., Correlation between stone weathering and environmental factors in marine atmosphere. Atmosp. Environ., 1995, 29(8), 895-903.

18. Aleena, S., Finding Portuguese Cochin. National Institute of Fashion Technology, Mumbai, 2001.

19. Miriello, D., Characterization of archaeological mortars from Pompeii (Campania, Italy) and identification of construction phases by compositional data analysis. J. Archaeol. Sci., 2010, 37(9), 2207-2223.

20. Sanjuro-Sanchez, Chemical and mineralogical characterization of historic mortars from the Santa Eulalia de Bóveda temple, NW Spain. J. Archaeol. Sci., 2008, 37(9), 2346-2351.

21. Villasenor, I. and Price, C. A., Technology and decay of magnesium lime plasters: the sculptures of the funerary crypt of Palenque, Mexico. J. Archaeol. Sci., 2010, 35(4), 1030-1039.

22. Ipekoglu, B., Boke, H. and Cizer, O., Assessment of material use in relation to climate in historical buildings. Build. Environ., 2007, 42, 970-978.

23. Boke, H., Cizer, O., Ipekoglu, B., Ugurlu, E., Serifaki, K. and Toprak, G., Characteristics of lime produced from limestone containing diatoms. Constr. Build. Mater., 2000, 22, 86.

24. Binici, H., Arocena, J., Kapur, S., Aksogan, O. and Kaplan, H., Investigation of the physicochemical and microscopic properties of ottoman mortars from Erzurum (Turkey). Constr. Build. Mater., 2010, 24, 1995-2002.

25. Binici, H. and Kapur, S., The physical, chemical and microscopic properties of the masonary mortars from Alhambra palace (Spain) in reference to their earthquake resistance. Front. Architect. Res., 2016, 5, 101-110.

26. Cultrone, G., Sebastián, E. and Huertas, M. O., Durability of masonry systems: a laboratory study. Constr. Build. Mater., 2007, 21, 40-51.

27. Boynton, R. S., Chemistry and Technology of Lime and Limestone, Wiley, New York, USA, 1980.

28. Cardell, C., Delalieux, F., Roumpopoulos, K., Moropoulou, A., Auger, F. and Van Grieken, R., Salt-induced decay in calcareous stone monuments and buildings in a marine environment in SW France. Const. Build. Mater., 2003, 17, 165-179.
29. RILEM, Recommandations provisoires/tentative recommendations, Commission 25-PEM, Protection et erosion des monuments: Essaisrecommandés pour mesurerl'altération des pierres et évaluerl'efficacité des méthodes de traitement. Matéri. Constr., 1980, 13, 175-253.

30. Koniorczyk, M. and Gawin, D., Modelling of salt crystallization in building materials with Microstructure-Poromechanical approach. Constr. Build. Mater., 2012, 36, 860-873; doi:10.1016/ j.conbuildmat.2012.06.035.

31. Bureau of Meteorology, Climate statistics for Australian locations: Adelaide, Government of Australia, 2008.

32. Lubelli, B., Sodium Chloride Damage to Porous Building Materials, Doctoral thesis, University of Technology, Delft, The Netherlands, 2006; http://resolver.tudelft.nl/uuid:c8d72659-ca2f-4a82aa5c-b4a39b6daaf8

33. Schmidt, H., Historical waterproofing-traditional and modern methods of moisture protection and wall drainage, 1999, 76, 581598.

34. Mustoe, G. E., The origin of honeycomb weathering. Geol. Soc. Am. Bull., 1982, 93, 108-115.

35. Haynes, H. et al., Concrete deterioration from physical attack by salts. Concrete Int., 1996, 18, 63-68.

36. Luque, A., Cultrone, G. and Sebastián, E., The use of lime mortars in restoration work on architectural heritage. In Materials, Technologies and Practice in Historic Heritage Structures (eds Dan, M. B., Přikryl, R. and Török, Á.), Springer, Dordrecht, 2010; https://doi.org/10.1007/978-90-481-2684-2_11.

37. Radonjic, M., Hallam, K. R., Allen, G. C. and Hayward, R. J., The mechanism of carbonation in lime-based materials. J. Building Limes Forum, 2001, 8, 50-64.

38. Cowper, A. D., Lime and Lime Mortars. Building Research Station and Building Research Establishment, Shaftesbury, Donhead, 1998.

ACKNOWLEDGEMENTS. We thank the Director General and Director (Science), Archaeological Survey of India, New Delhi for their support during this study.

Received 23 June 2020; accepted 12 October 2020

doi: $10.18520 / \mathrm{cs} / \mathrm{v} 120 / \mathrm{i} 3 / 538-546$ 